\title{
Microbial contamination of Naira notes circulating in Bauchi metropolis: prevalence, microbial load and detection of extended spectrum beta-lactamase producing Gram-negative bacteria
}

\author{
${ }^{1}$ Usman, M., ${ }^{2}$ Sani J., ${ }^{3}$ Ibrahim, A., and ${ }^{* 4}$ Olowo-okere, A \\ ${ }^{1}$ Department of Pharmacy, Nigerian Air Force Reference Hospital, Bauchi, Nigeria \\ ${ }^{2}$ Department of Clinical Pharmacy, Kaduna State University, Kaduna, Nigeria \\ ${ }^{3}$ Department of Medical Microbiology, Abubakar Tafawa Balewa Teaching Hospital, Bauchi, Nigeria \\ ${ }^{4}$ Department of Pharmaceutics and Pharmaceutical Microbiology, Usmanu Danfodiyo University, Sokoto, Nigeria \\ *Correspondence to: olowoahmed@gmail.com
}

\begin{abstract}
:
Background: Globally, contamination of banknotes with various microbial species is increasingly being reported. This usually results from improper handling during exchange of goods and services. In the present study, we aimed to determine the microbial load, prevalence and the presence of Extended Spectrum Beta Lactamase (ESBL) among bacteria isolated from the Nigerian Naira notes circulating in Bauchi metropolis.

Methodology: A total of 400 Naira notes of various denominations were randomly collected aseptically, cultured and total viable counts determined. The isolated microbial species were identified using standard microbiological techniques. Antibiotic susceptibility of the isolates and detection of ESBL were determined by Kirby-Bauer's disc diffusion method and Double Disc Synergy Test (DDST), respectively.

Results: All the 400 samples collected were contaminated with various microbial species. The highest mean colony count was detected in 20 Naira notes (28.5\%), while the least was observed in 1000 Naira note (3.3\%). Fourteen different microbial species were isolated from the contaminated currency notes, predominantly Escherichia coli (25.0\%), and Staphylococcus aureus (12.0\%). Some fungal species mainly Aspergillus flavus and Aspergillus niger were also isolated. Majority of the bacteria isolates resistant to the third generation cephalosporins $(72.1 \%)$ were ESBL positive.

Conclusion: The study shows that Naira notes circulating in Bauchi metropolis were heavily contaminated with various microbial species, and a high proportion of the isolated Gram-negative bacteria were ESBL producers. Efforts should thus be made to improve hygiene practices in the study area. Importantly, businesses should be encouraged to adopt the use of electronic transactions.
\end{abstract}

Keywords: Currency notes, Naira, Microbial contamination, ESBL

Received Jul 24, 2020; Revised Jan 2, 2021; Accepted Jan 3, 2021

Copyright 2021 AJCEM Open Access. This article is licensed and distributed under the terms of the Creative Commons Attrition 4.0 International License <a $\mathrm{rel}="$ license" href="http://creativecommons.org/licenses/by/4.0/", which permits unrestricted use, distribution and reproduction in any medium, provided credit is given to the original author(s) and the source. Editor-in-Chief: Prof. S. S. Taiwo

\section{Contamination microbienne des notes de Naira circulant dans la métropole de Bauchi: prévalence, charge microbienne et détection de la production de bêta-lactamase à spectre étendu Bactéries Gram-négatives}

\author{
${ }^{1}$ Usman, M., ${ }^{2}$ Sani J., ${ }^{3}$ Ibrahim, A., et *4Olowo-okere, A \\ ${ }^{1}$ Département de pharmacie, Hôpital de référence de l'armée de l'air nigériane, Bauchi, Nigéria \\ ${ }^{2}$ Département de pharmacie clinique, Université d'État de Kaduna, Kaduna, Nigéria \\ ${ }^{3}$ Département de microbiologie médicale, Hôpital universitaire Abubakar Tafawa Balewa, Bauchi, Nigéria
}


${ }^{4}$ Département de pharmacie et de microbiologie pharmaceutique, Université Usmanu Danfodiyo, Sokoto, Nigéria *Correspondance à: olowoahmed@gmail.com

\begin{abstract}
Abstrait:
Contexte: À l'échelle mondiale, la contamination des billets de banque par diverses espèces microbiennes est de plus en plus signalée. Cela résulte généralement d'une mauvaise manipulation lors de l'échange de biens et de services. Dans la présente étude, nous avons cherché à déterminer la charge microbienne, la prévalence et la présence de bêta lactamase à spectre étendu (BLSE) parmi les bactéries isolées des notes nigérianes naira circulant dans la métropole de Bauchi.

Méthodologie: Un total de 400 billets Naira de différentes dénominations ont été collectés au hasard de manière aseptique, cultivés et le nombre total viable déterminé. Les espèces microbiennes isolées ont été identifiées à l'aide de techniques microbiologiques standard. La sensibilité aux antibiotiques des isolats et la détection des BLSE ont été déterminées respectivement par la méthode de diffusion sur disque de Kirby-Bauer et le test de synergie à double disque (DDST).

Résultats: Tous les 400 échantillons prélevés étaient contaminés par diverses espèces microbiennes. Le nombre moyen de colonies le plus élevé a été détecté dans 20 billets nairas (28,5\%), tandis que le moins a été observé dans les billets 1000 nairas (3,3\%). Quatorze espèces microbiennes différentes ont été isolées des billets de banque contaminés, principalement Escherichia coli $(25,0 \%)$ et Staphylococcus aureus $(12,0 \%)$. Certaines espèces fongiques, principalement Aspergillus flavus et Aspergillus niger, ont également été isolées. La majorité des isolats bactériens résistants aux céphalosporines de troisième génération $(72,1 \%)$ étaient BLSE positifs.

Conclusion: L'étude montre que les notes de Naira circulant dans la métropole de Bauchi étaient fortement contaminées par diverses espèces microbiennes et qu'une forte proportion des bactéries Gram-négatives isolées étaient des producteurs de BLSE. Des efforts devraient donc être faits pour améliorer les pratiques d'hygiène dans la zone d'étude. Surtout, les entreprises devraient être encouragées à adopter l'utilisation des transactions électroniques.
\end{abstract}

Mots clés: billets de banque, naira, contamination microbienne, BLSE

\section{Introduction:}

Bank currency notes are the commonest means of exchanging goods and services particularly in developing countries (1). They are one of the most frequently passed items from one hand to the other during transactions (2). Improper handling practices such as concurrent handling of banknotes and food items, use of saliva to wet fingers during counting, placing or storing paper notes in or on dirty surfaces among others has led to widespread contamination of banknotes with various microbial species (3).

Globally, contamination of banknotes with microbial species is being reported. A large multi-national study involving 1280 banknotes obtained from 10 different countries showed that bacterial contamination of banknotes is greatly influenced by age of the notes and the nature of material used to produce the notes (polymer-based versus cotton-based) (4). In the United States, 94\% contamination of circulating one dollar bill was reported in 2002 (5). A similar high contamination rate has been reported in Estonia (6), Pakistan (7), Croatia (2) and Ghana (8).

The contaminated banknotes have been demonstrated to be a viable source of crosscontamination and a vehicle for transmission of infectious agents in the community (9). Bacteria causing foodborne diseases such as typhoid fever, gastroenteritis, shigellosis, etc have been isolated from banknotes $(10,11)$. Some other researchers have isolated parasites and viral particles from bank currency notes (12-14).

Studies across Nigeria have documentted varying rate of microbial contamination of banknotes (15-17). In Bauchi, north-eastern Nigeria, the level of microbial bioburden and the prevalence of extended spectrum beta-lactamase (ESBL) among the circulating Naira notes is currently unknown. In the present study, we aimed to determine the microbial load, prevalence and the presence of ESBL among bacteria isolated from the Nigerian Naira notes circulating in Bauchi metropolis.

\section{Materials and method:}

\section{Study setting}

The study was carried out in the main market (Wunti market) in Bauchi metropolis, the capital of Bauchi State (geographic coordinates $10.7761^{\circ} \mathrm{N}, 9.9992^{\circ} \mathrm{E}$ ). The city has an estimated population of $6,537,314$, approximately $3.38 \%$ of the Nigerian population (18). The market is located in the heart of Bauchi metropolis, serving as point of exchange of goods and services for the inhabitants of the State. Field survey showed that the market has 2980 shops operating various businesses ranging from grocery stores, fashion houses, butcher houses, snack bars, canteens, and hardware shops. 


\section{Study design and sampling method}

This was a descriptive cross-sectional study of Naira currency denominations among market shop owners, conducted between January and July 2019. Systematic random sampling method was used to select shops for participation in this study. Samples were collected from every $5^{\text {th }}$ shop in the study area.

\section{Ethical considerations}

The approval to conduct this study was granted by the Bauchi State Ministry of Health (Ref No: NREC/12/05/2013/2017/38). Consent was also sought from the market men and women after carefully briefing them on the objective of the study.

\section{Selection criteria}

All the Naira currency denominations currently in use in Nigeria from the selected shop owners were included with the exception of the mutilated or grossly dirty notes. The samples were collected from only numbered shops. Constructed road side/temporary shops without numbering were excluded. Also, old notes that have been withdrawn from circulation were also excluded from the study.

\section{Sample collection}

Fifty (50) samples of each of the eight

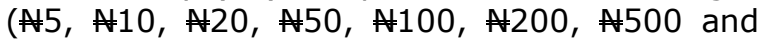
$\$ 1,000)$ Naira denominations in circulation total ling 400 samples were collected from different shop owners practicing different businesses of their choice in Wunti market in the metropolis of Bauchi State, Nigeria. The Naira note samples were collected aseptically by letting the owners drop them into sterile polythene bags, and the polythene sealed immediately. The sealed polythene bags were immediately taken to the Medical Microbiological Laboratory of the Abubakar Tafawa Balewa University Teaching Hospital in Bauchi.

\section{Enumeration of microbial contaminants}

The enumeration of microbial contaminants on the notes was carried out as previously described (17). Briefly, the collected Naira notes were placed aseptically into different sterile test tubes containing $10 \mathrm{ml}$ of sterile water and shaken for few minutes. After 3 minutes, the notes were removed from the test tubes and a 5 serial 10 -fold dilution $\left(10^{-1}\right.$ to $\left.10^{-5}\right)$ were made. An aliquot of $0.1 \mathrm{ml}$ from the $10^{-4}$ dilution was aseptically inoculated on Blood, MacConkey and Mannitol salt agar plates which had been prepared according to manufacturer's instruction. All plates were incubated at $37^{\circ} \mathrm{C}$ for 24 hrs, and examined for bacterial growth, and the number of colonies on each plate was counted using a digital colony counter.

Identification of bacterial isolates was done using a combination of morphological characteristics such as shape, colour, elevation, consistency etc. and biochemical characteristics including coagulase, novobiocin, triple sugar iron (TSI) agar, oxidase, catalase, oxidationfermentation (OF), urease, motility, indole, citrate, methyl red (MR) and Voges-Proskauer (VP) tests as previously described (19).

For isolation of fungi, a loopful of the culture was inoculated in duplicate onto Sabouraud's Dextrose agar (SDA) supplemented with $0.01 \%$ chloramphenicol. The first plate was incubated aerobically at $37^{\circ} \mathrm{C}$ for 48 hours and the second plate was incubated for five days at room temperature $\left(25^{\circ} \mathrm{C}\right)$. Identification was done on the basis of cultural (mould or yeast form, pigment production) and microscopic morphological characteristics following staining with lactophenol cotton blue as described (20).

\section{Antibiotic susceptibility testing}

Antimicrobial susceptibility pattern of bacterial isolates was determined using the disc diffusion method according to the Clinical and Laboratory Standards Institute (CLSI) guidelines (21). The tested antibiotics were as follow; ampicillin, ciprofloxacin, gentamicin, nalidixic acid, amoxicillin, aztreonam, cefoxitin, vancomycin, tetracycline and erythromycin (Mast company, UK). The standard strain of $E$. coli ATCC 25922 was used for quality control in susceptibility testing. Interpretation of results as susceptible, intermediate or resistant was done according to the criteria recommended by the CLSI guideline.

\section{Screening test for ESBLs}

Gram negative bacterial isolates resistant to third generation cephalosporins (3GC) were regarded as presumptive ESBL positive. This was confirmed by the double discs synergy test (DDST). Briefly, the confirmatory test was performed by placing a $\beta$-lactamase inhibitor (amoxicillin-clavulanic) disc between two third generation cephalosporins (3GCs) discs at a distance of $20 \mathrm{~mm}$ centre-to-centre on a plate 
inoculated with a standardized inoculum of the test organism as previously described [22]. Formation of a characteristic keyhole effect or champagne-cork shaped zone of inhibition between the discs was considered as a phenotypic indication of ESBL production.

\section{Statistical analysis}

Data was analysed using IBM SPSS statistics software, version 24.0 (IBM Corporation, Armonk, NY) and presented as simple descriptive statistics or pictograms. Categorical variables were compared using Pearson's $X^{2}$ test or Fisher's exact test. At $95 \%$ confidence interval, $p<0.05$ was considered as statistically significant.

\section{Results:}

\section{Mean microbial counts on each of the currency denominations}

A total of 400 Naira notes samples of

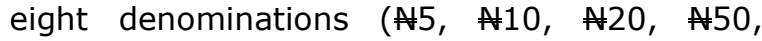
$\# 100, \# 200, \# 500$ and $\# 1,000)$ were collected from traders within the market. All the samples analysed were contaminated with various microbial species. The result of mean colony counts of the different currency denominations sampled from the markets is presented in Table 1.

Table 1: Mean colony counts of microbial pathogens across the currency notes

\begin{tabular}{ccc}
\hline $\begin{array}{c}\text { Currency } \\
\text { denominations }\end{array}$ & \multicolumn{2}{l}{ Mean colony counts $\left(\mathrm{CFU} / \mathrm{ml} \times 10^{3}\right)$} \\
\cline { 2 - 3 } 1000 & $7.0 \pm 0.4$ & Fungi \\
500 & $9.0 \pm 0.7$ & $11.0 \pm 0.9$ \\
200 & $15.0 \pm 0.5$ & $12.0 \pm 0.4$ \\
100 & $24.0 \pm 0.1$ & $13.0 \pm 0.5$ \\
50 & $21.0 \pm 0.6$ & $6.0 \pm 0.1$ \\
20 & $48.0 \pm 0.1$ & $5.0 \pm 0.7$ \\
10 & $39.0 \pm 0.5$ & $5.0 \pm 0.2$ \\
5 & $34.0 \pm 0.4$ & $4.0 \pm 0.1$ \\
\hline CFU = Colony Forming Unit; $\mathrm{ml}=$ Millilitre &
\end{tabular}

The result shows that 20 Naira notes had the highest mean count of $48.0 \pm 0.1 \times 103$ $\mathrm{CFU} / \mathrm{ml}$ for bacteria, followed by 10 Naira note which had $39.0 \pm 0.5 \times 103 \mathrm{CFU} / \mathrm{ml}$ while 1000 Naira notes had the least count of $7.0 \pm 0.4 \times 103$ $\mathrm{CFU} / \mathrm{ml}$. The fungal count of the Naira notes revealed that 100 Naira note has the highest count of $13.0 \pm 0.5 \times 103 \mathrm{CFU} / \mathrm{ml}$, followed by 200 Naira with $12.0 \pm 0.4 \times 103 \mathrm{CFU} / \mathrm{ml}$ while the least was 5 Naira note which had $4.0 \pm 0.2 \times 103$ CFU/ml (Table 1).

\section{Distribution of the microbial isolates according to different denominations}

As shown in Table 2, the highest contamination rate was in 20 Naira notes 114 (28.5 $\%)$, followed by 50 Naira note $64(17.5 \%)$, and the least rate was in 1000 Naira note 13 (3.3\%).

Table 2: Distribution of the microbial isolates according to different currency denominations

\begin{tabular}{cc}
\hline Banknotes & Contamination \\
\hline 1000 & $23(5.3)$ \\
500 & $40(10.0)$ \\
200 & $53(13.3)$ \\
100 & $64(16.0)$ \\
50 & $114(28.5)$ \\
20 & $56(14.0)$ \\
10 & $37(9.3)$ \\
5 &
\end{tabular}

\section{Distribution of isolated microbial contaminants} The distribution of isolated organisms is presented in Table 3. Fourteen different microbial species were isolated from the contaminated currency notes. Escherichia coli (25.0\%) and Klebsiella pneumoniae (24.5\%), were the commonest Gram-negative bacteria isolated. This was followed by Klebsiella oxytoca, Proteus spp and Pseudomonas aeruginosa. Among the Gram-positive bacteria isolated, Staphylococcus aureus (12.0\%) and Bacillus spp (3.5\%) were the most frequently encountered. Some fungal species were also isolated, mainly Aspergillus flavus, Rhizopus spp and Aspergillus niger. 
Table 3: Distribution of isolated microbial species

\begin{tabular}{|c|c|c|}
\hline Isolates & Number (n) & Percentage (\%) \\
\hline \multicolumn{3}{|l|}{ Gram-negative bacteria $(n=280)$} \\
\hline Escherichia coli & 100 & 25 \\
\hline Klebsiella pneumoniae & 98 & 24.5 \\
\hline Klebsiella oxytoca & 40 & 10 \\
\hline Proteus spp & 28 & 7 \\
\hline Pseudomonas aeruginosa & 10 & 2.5 \\
\hline Enterobacter spp & 2 & 0.5 \\
\hline Salmonella typhimurium & 2 & 0.5 \\
\hline \multicolumn{3}{|l|}{ Gram-positive bacteria $(n=140)$} \\
\hline Staphylococcus aureus & 48 & 12 \\
\hline Staphylococcus saprophyticus & 10 & 2.5 \\
\hline Bacillus spp & 14 & 3.5 \\
\hline Micrococcus spp & 2 & 0.5 \\
\hline \multicolumn{3}{|l|}{ Fungal isolates } \\
\hline Aspergillus flavus & 18 & 4.5 \\
\hline Rhizopus spp & 18 & 4.5 \\
\hline Aspergillus niger & 10 & 2.5 \\
\hline Total & 400 & 100 \\
\hline
\end{tabular}

Table 4: Distribution of ESBL producing among multidrug resistant Enterobacteriaceae isolates from Naira notes

\begin{tabular}{ccc}
\hline Isolates & Number of 3GC resistant isolates & No of ESBL positive (\%) \\
\hline Escherichia coli & 19 & $26(30.2)$ \\
Klebsiella oxytoca & 2 & $5(5.8)$ \\
Klebsiella pneumoniae & 44 & $0(0)$ \\
Proteus spp & 14 & $0(0)$ \\
Salmonella typhimurium & 1 & $8(9.6)$ \\
Pseudomonas aeruginosa & 5 & $1(1.2)$ \\
\hline Enterobacter spp. & 1 & $\mathbf{6 2}(\mathbf{7 2 . 1})$ \\
\hline Total & $\mathbf{8 6}$ & $(9.3)$ \\
\hline
\end{tabular}

\section{Antibiotic resistance pattern of the isolated bacteria}

Out of the total of 280 Gram-negative bacterial isolated from various Naira notes, 86 $(30.7 \%)$ were resistant to third generation cep- halosporins (3GC). The 3GC resistant isolates comprise E. coli $(n=19), K$. oxytoca $(n=2), K$. pneumoniae $(n=44)$, Proteus spp $(n=14)$, Salmonella typhimurium $(\mathrm{n}=1), P$. aeruginosa 
$(\mathrm{n}=5)$, and Enterobacter spp $(\mathrm{n}=1)$. The result of phenotypic ESBL detection showed that 62 $(72.1 \%)$ of the $3 G C$ resistant bacteria were ESBL positive (Table 4). This was predominantly detected among $E$. coil $26(30.2 \%)$ and $K$. pneumoniae $5(5.8 \%)$ isolates.

\section{Discussion:}

The contamination of paper currency notes is almost inevitable due to poor handling practices. In this study, $100 \%$ contamination rate was observed. This is consistent with high contamination rate reported by other researchers across the country (23). Similarly, in a neighbouring West Africa country, $100 \%$ contamination rate was reported (8). One hundred percent contamination rate of Pakistani and Euro currency notes have also been reported $(24,25)$. The contamination may have aroused from simultaneous handling of the currency notes and various articles during exchange at selling points (26). This practice is particularly common among small businesses in the study area due to low level of penetration and acceptance of electronic transaction as a result of high internet cost and low-literacy level in the area $(27,28)$. Additionally, activities of cyber-criminals popularly known as 'Yahoo-Yahoo' using deceptive banking tools to defraud unsuspecting clients makes the use of physical currency very popular, with attendant health risks (29). Though variation in mean colony counts among currency of the same denomination exist, the heavy contamination of lower denomination currencies ( $\$ 100$ to $\# 5$ ) observed in this study concurs with the findings of other researchers $(30,31)$. This may be attributed to high use and frequent exchange of lower denomination currencies than the higher denominations in daily cash transactions (31).

The contamination of the notes with several known human pathogens concurs with several other reports $(30,32)$. The predominance of $E$. coli and other enteric Gram-negative bacteria among the isolated bacteria may be due to poor hygiene (both personal and environmental) in the study area. This is in contrast with a result of a study in Uganda where $E$. coli isolates were not detected among the bacteria isolated from their paper currency notes (30). Similar to the finding of this study, currency notes in both Nigeria and elsewhere have been shown to be contaminated with various fungal isolates $(11,33,34)$. Among the Gram-positive bacteria, Staphylococcus spp predominates. This could have been shed from the skin of the hands during handling and exchange (34).

The high ESBL detection rate $(72.1 \%)$ in the isolated bacteria is not surprising. This is in line with $7.593 .3 \%$ rate reported in a systematic review on the prevalence of ESBL producing Gram-negative bacteria in Nigeria (35). Another study has reported contamination of automated teller machine (ATM) touch surfaces by ESBL producing bacteria (36). Bacteria harbouring other antibiotic resistance mechanisms have also been isolated from Nigerian currency notes (23). The high ESBL rate among the isolated bacteria may be due to overuse of betalactam antibiotics in the study area (37). In Nigeria generally, beta-lactam antibiotics are the most widely used in both hospital and community settings (38). Sometimes, these antibiotics are sourced over-the-counter for self-medication (39). This practice has over the years led to the emergence of beta-lactamase producing bacteria threatening the therapeutic efficacy of most the beta-lactam antibiotics.

The finding in this study has significant health implications. Majorly, the contaminated currency notes may serve as vehicle for transmission of infectious agents, playing significant role in the community transmission of infectious agents (3). This is worrisome particularly in this era of global pandemic due to SARS-CoV-2. Moreover, handlers of these notes especially women may put the currency notes in their brassieres or other areas where there is intimate contact with the skin and thus predisposing them to infections. Also, some individuals usually wet their fingers with saliva to ease the counting of the currencies, consequently resulting in cross-contamination. Food vendors too simultaneously handling monies and ready to eat food could also facilitate the transmission of potential pathogenic organisms from currencies to their clients.

Preventive measures aimed at breaking the chain of transmission of infections and contamination of the currency notes should therefore be instituted. This should include public enlightenment on personal and environmental hygiene and proper handling of Naira notes. Old and mutilated notes should be frequently withdrawn and replaced. Lastly and most importantly, electronic transactions such as the use of digital money, point of service (POS), electronic transfer of fund and others should urgently be promoted as a safer alternative.

This study was characterised by some limitations. First, the study was restricted to bacterial and fungal contaminants. Potential contamination by viruses and some pathogenic parasites could not be inferred. Also, the ESBL detection test was restricted to phenotypic method. As such, the predominant genotype of 
the detected ESBL producing strains remains unknown. Recently, genotypic methods including meta-genomics is being explored for investigation of microbial pathogens and antibiotic resistance genes on currency notes (14). However, until now, no previous report on the microbial contamination of Naira notes in the State. This study thus provides an important baseline data on contamination of Naira notes in Bauchi State, North-eastern Nigeria.

\section{Conclusion:}

The study shows that Naira notes circulating in Bauchi metropolis were heavily contaminated with microbial species, predominantly E. coli, K. pneumoniae and $S$. aureus. A high proportion (72.1\%) of the isolated Gram-negative bacteria were ESBL producers. Because of the potential role of banknotes in transmission of pathogenic organisms, advocacy to improve hygiene practices in the study area should be urgently undertaken. Most importantly, businesses should be encouraged to adopt safer alternatives such as the use of electronic transactions.

\section{Authors' contributions:}

The study was designed and conducted by $\mathrm{MU}$ and $\mathrm{AI}$. AO analysed and interpreted the data and produced the first manuscript draft, which was revised by all authors. All authors read and approved the final manuscript.

\section{Conflict of interest:}

Authors declare no conflict of interest

\section{References:}

1. Das, A. Money as a Medium of Exchange: Then and Now: Can Technology be a Facilitator of Exchange? Glob J Manag Bus Res. 2015; 15: 1-7.

2. Gedik, H., Voss, T. A., and Voss, A. Money and transmission of bacteria Money and transmission of bacteria. Antimicrob Resist Infect Contr. 2013; 2: $1-4$.

3. Girma G. Health Risk Associated with Handling of Contaminated Paper Currencies in. Int J Food Nutr Sci. 2016; 2: 1-5.

https://doi.org/10.15436/2377-0619.15.014.

4. Vriesekoop, F., Russell, C., Alvarez-mayorga, B., et al. Dirty Money: An Investigation into the Hygiene Status of Some of the World's Currencies as Obtained. Foodborne Pathog Dis. 2010; 7: 14971503.

5. Pope, T. W. Bacterial contamination of Paer Currrency. South Med J. 2002; 12: 1408-1414.

6. Mändar, K., Sõber, T., Kõljalg, S., Rööp, T., and Mändar, R. Microbiological contamination of the Euro currency in Estonia. Infect Dis (Auckl). 2016; 4235:773-780. https://doi.org/10.1080/23744235.2016.1201725.

7. Ejaz, H., Javeed, A., and Zubair, M. Bacterial contamination of Pakistani currency notes from hospital and community sources. Pak J Med Sci. 2018; 34: 1225-1230.

8. Tagoe, D., Baidoo, S., Dadzie, I., and Ahator, D. A study of Bacterial Contamination of Ghanaian Currency Notes in Circulation. Internet J Microbiol. 2009; 8: 1-5.

9. Kesavan, J., Stephens, A., and Kesavan, M. Bacterial Cross-contamination Potential Associated with Contaminated Currency. J Forensic Sci. 2016: 1-4. https://doi.org/10.1111/1556-4029.13174.

10. Parajuli, N. P., Joshi, G., Pardhe, B. D., et al. Shigellosis Caused by CTX-M Type ESBL Producing Shigella flexneri in Two Siblings of Rural Nepal: First Case Report from the Country. Case Rep Infect Dis. 2017;2017:1-5

https://doi.org/10.1155/2017/1862320.

11. Saadabi, A. M. A., Alhussaini, M. S., Al-ghanayem, A. A., Joseph, B., and Shuriam, M. S. Isolation and Identification of Pathogenic Bacteria and Fungi from Some Saudi Bank Note Currency. Biosci Biotechnol Res Asia. 2017; 14: 715-720.

12. Simon-oke, I. A., and Ajileye, O. D. Evaluation of Parasites as Contaminants of Currency Notes in Akure, Nigeria. Int J Enteric Pathog. 2019; 7: 4448.https://doi.org/10.15171/ijep.2019.11.

13. Tosin, A., Adeniyi, O. T., and Bunmi, A. O. Parasitological and Bacterial Contamination of Nigerian Currency Notes and the Antimicrobial Resistance of the Isolates in Akure, Southwestern Nigeria. Mol Microbiol Res. 2019; 9: 1-8. https://doi.org/10.5376/mmr.2019.09.0001.

14. Jalali, S., Kohli, S., Latka, C., and Bhatia, S. Screening Currency Notes for Microbial Pathogens and Antibiotic Resistance Genes Using a Shotgun Metagenomic Approach. PLoS One. 2015; 10: 1-15. https://doi.org/10.1371/journal.pone.0128711.

15. Awe, S., Eniola, K. I. T., Ojo, F. T., and Sani, A. Bacteriological quality of some Nigerian currencies in circulation. Afri J Microbiol Res. 2010; 4: 22312234.

16. Leonard, O. A., and Olajumoke, M. Parasite Contamination of Nigerian Currencies in Ibadan City, South-West Nigeria. Annu Res Rev Biol. 2016; 10:1-6.

https://doi.org/10.9734/ARRB/2016/24735.

17. Uko, M. P., Uko, I. C., Umana, S. I., and Bassey, M. P. Microbial Load, Prevalence and Antibiotics Susceptibility of Bacteria Isolated From Naira Notes. Asian J Biotechnol Biores Technol. 2017; 1: 1-8. https://doi.org/10.9734/AJB2T/2017/35777.

18. Nigerian Bureau of Statistics. Demographic Statistics. 2017. https://doi.org/10.1016/b978-012-527850-8.50022-5.

19. Cowan, T., and Steel, K. Cowan and Steel manual for the identification of medically important bacteria. 3rd ed. New York: Cambridge University Press; 1993.

20. Cheesebrough M. District Laboratory Practice in Tropical Countries. Cambridge CB2 8RU, UK: California State University; 2006.

21. Clinical and Laboratory Standards Institute (CLSI). M100S Performance Standards for Antimicrobial Susceptibility Testing. Wayne, PA 19087 USA: 2019.

22. Olowo-okere, A., Ibrahim, Y. K. E., and Olayinka, B. O. Molecular characterisation of extended-spectrum $\beta$-lactamase-producing Gram-negative bacterial isolates from surgical wounds of patients at a hospital in North Central Nigeria. J Glob Antimicrob Resist. 2018; 14: 85 - 89 https://doi.org/10.1016/j.jgar.2018.02.002.

23. Aminu, B. M., and Yahaya, H. Antibiotic sensitivity pattern of bacteria isolated from Nigerian currencies 
(Naira) circulating in some hospitals of Kano metropolis, Kano State, Nigeria. Bayero J Pure Appl Sci. 2018; 11: 185-190.

24. Sharif, M., and Ansari, F. Assessment of Bacterial Load On Pakistani Currency Notes and Coins in Circulation. Eur J Biomed Pharm Sci. 2017; 4: 474481.

25. Gabriel, E. M., Coffey, A., and Mahony, J. M. O. Investigation into the prevalence, persistence and antibiotic resistance profiles of staphylococci isolated from Euro currency. J Appl Microbiol. 2013; 115: 565-571. https://doi.org/10.1111/jam.12247.

26. Alabbasy, A. J. International Journal of Environmental Chemistry. A Literature Review on Microbial Contamination of Paper Currency 2019.

27. Nwankwo, O. Electronic Payment in Cashless Economy of Nigeria: Problems and Prospect. J Manag Res. 2013; 5: 138-151.

https://doi.org/10.5296/jmr.v5i1.2650.

28. Nedozi, F. O., and Omoregie, C. I. An Empirical Evaluation of Different Electronic Payment Channels in Nigeria. J Financ Account. 2019; 7: 146 - 152. https://doi.org/10.11648/j.jfa.20190705.13.

29. Richard, E. Effect of Inflation Rate on Insurance Penetration of Nigerian Insurance Industry 2019. https://doi.org/10.5296/jmr.v5i1.2650.

30. Allan, M., Atuhaire, C., Nathan, M., Ejobi, F., and Cumber, S. N. Bacterial contamination of Ugandan paper currency notes possessed by food vendors around Mulago Hospital complex, Uganda. Pan Afr Med 2018; 31: 1-7 https://doi.org/10.11604/pamj.2018.31.143.16738.

31. Alemayehu, H., and Ashenafi, M. Microbial load of Ethiopian currency notes collected from various sources. Int J Adv Res Biol Sci. 2019; 6: 119-126. https://doi.org/10.22192/ijarbs.

32. Musa, F. M., Orukotan, A. A., Mohammed-Idris, Z. K., et al. Bacterial Contamination of Nigerian
Currency Notes Currency Notes Circulating Within Selected Markets in Kaduna Metropolis. Bayero J Pure Appl Sci. 2019; 12: 366-371.

33. Ukwuru, M. U., and Gabriel, A. Cross contamination between food and money due to simultaneous handling. J Appl Sci Environ.2012;3:42-48.

34. Akoachere, J. T. K., Gaelle, N., Dilonga, H. M., and Nkuo-akenji, T. K. Public health implications of contamination of Franc CFA (XAF) circulating in Buea (Cameroon) with drug resistant pathogens. BMC Res Notes. 2014; 7

35. Tanko, N., Bolaji, R. O., Olayinka, A. T., and Olayinka, B. O. A systematic review on the prevalence of extended spectrum beta lactamase producing Gram-negative bacteria in Nigeria. J Glob Antimicrob Resist 2020; 22: 488 - 496. https://doi.org/10.1016/j.jgar.2020.04.010.

36. Ungokore, $\mathrm{H}$, . Omole, O., Nuhu, T., et al. Phenotypic Detection of Extended Spectrum $\beta$ Lactamase and Metallo- $\beta$-Lactamase Produced by Escherichia coli on Automated Teller Machines within Sokoto. J Appl Sci Environ Manag. 2019; 23: 93-97. doi:https://dx.doi.org/10.4314/jasem.v23i1.15.

37. Ventola, C. L. The Antibiotic Resistance Crisis Part 1: Causes and Threats. Pharm Ther. 2015; 40: 277-283.

38. Olowo-okere, A., Abdullahi, M. A., Ladidi, B. K., et al. Emergence of Metallo-Beta-Lactamase Producing Gram-Negative Bacteria In A Hospital With No History Of Carbapenem Usage In Northwest Nigeria. Ife J Sci. 2019; 21: 1-9.

39. Ajibola, O., Omisakin, O. A., Eze, A. A., and Omoleke, S. A. Self-Medication with Antibiotics, Attitude and Knowledge of Antibiotic Resistance among Community Residents and Undergraduate Students in Northwest Nigeria. Diseases. 2018; 6: 1-14. https://doi.org/10.3390/diseases6020032. 